\title{
RELATIONSHIP BETWEEN TOTAL TREE HEIGHT AND DIAMETER AT BREAST HEIGHT FOR TROPICAL PEAT SWAMP FOREST TREE SPECIES IN ROKAN HILIR DISTRICT, RIAU PROVINCE
}

\author{
Nunung Puji Nugroho ${ }^{1 *}$ \\ Received : 1 November 2012, Accepted : 12 March 2014
}

\begin{abstract}
Reliable information on total tree height $(H)$ is fundamental of forest resource management and forest ecological studies, including assessment of forest biomass. Adding an $H$ variable can improve the performance of the allometric equations of the biomass by reducing the average deviation significantly. However, measuring $H$ is relatively complex, less accurate, time consuming, and expensive. Thus, $H$ is only measured for sampled trees within the plots, whilst diameter at breast height (DBH) is commonly measured for each tree during the forest inventory. The missing $H$ information is usually estimated based on a stand-specific allometric relationship between $H$ and $\mathrm{DBH}$ ( $H-D$ model) constructed from sampled trees. Despite extensive studies on $H-D$ model for boreal forests and for single-species/plantation forests, few studies have focused on tropical forests. Furthermore, relationship for peat swamp forest tree species, and especially those in Indonesia, have not been widely published. Thus, the objective of this study was to develop site-specific H-D models for tropical peat swamp forests using linearized and non-linear regression functions. The results indicated that the non-linear models outperformed the linearized models based on the statistical parameters and the biological criteria. The modified logistic function (Model 7) is recommended for estimating $H$ in the study area as it has comparable model performances to the exponential function (Model 6) and passed the diameter-height point of $(0,1.3)$. However, all five non-linear models performed equally well and the differences between them were trivial. Further improvements are needed to improve the accuracy, the predictive ability and the geographical applicability of the models by grouping the species, adding stand variables and (or) using advanced techniques of mixed-effect modelling. In addition, model validation should be carried out prior to their application by collecting new datasets from the forest being studied.
\end{abstract}

Keywords: Site-specific, height-diameter model, linearized and non-linear regression functions, peat swamp forest, Indonesia

\begin{abstract}
ABSTRAK
Informasi tinggi pohon total $(H)$ yang dapat dipercaya adalah sangat penting dalam pengelolaan sumberdaya hutan dan kajian-kajian ekologi hutan, termasuk dalam penaksiran biomassa hutan. Penambahan peubah $H$ dapat meningkatkan performa dari persamaan alometrik biomassa dengan mengurangi ratarata penyimpangan secara nyata. Namun demikian, pengukuran $H$ adalah rumit, kurang akurat, memakan waktu, dan mahal. Jadi, $H$ hanya diukur untuk pohon-pohon contoh di dalam plot, sedangkan diameter setinggi dada $(D)$ umumnya diukur untuk setiap pohon selama kegiatan inventarisasi hutan. Informasi $H$ yang hilang/tidak lengkap tersebut biasanya diduga berdasarkan suatu hubungan alometrik antara $H$ dan $D$ yang dibangun dari pohon-pohon contoh. Meskipun banyak kajian tentang pemodelan hubungan antara $H$ dan $D$ untuk hutan boreal dan untuk hutan jenis tunggal/tanaman, sedikit kajian yang fokus pada hutan
\end{abstract}

\footnotetext{
Technology and Watershed Management Research Institute, Jl. Jend. A. Yani Pabelan Kotak Pos 295, Surakarta, Central Java 57012 - Indonesia *Corresponding author: np_nugroho04@yahoo.com
} 
tropis. Lebih lanjut lagi, hubungan tersebut untuk jenis-jenis pohon di hutan rawa gambut, dan terutama di Indonesia, belum terpublikasi secara luas. Jadi, tujuan dari kajian ini adalah untuk mengembangkan tapak spesifik model $H-D$ untuk hutan rawa gambut dengan menggunakan fungsi regresi linier dan nonlinier. Hasil dari kajian ini menunjukkan bahwa performa model-model non-linier lebih baik daripada yang linier berdasarkan parameter statistik dan kriteria biologis. Fungsi logistik yang dimodifikasi (Model 7) direkomendasikan untuk menduga $H$ di wilayah kajian karena model ini mempunyai performa yang sebanding dengan fungsi eksponensial (Model 6) dan melalui titik diameter dan tinggi dengan nilai $0 \mathrm{~cm}$ dan 1,3 m. Namun demikian, kelima model non-linier tersebut mempunyai performa yang sebanding bagusnya dengan perbedaan yang tidak berarti. Perbaikan lebih lanjut dibutuhkan untuk meningkatkan keakurasian, kemampuan prediksi dan penerapan geografis dari model yang dikembangkan dengan mengelompokkan jenis-jenis pohonnya, menambahkan peubah yang mencirikan tegakan dan (atau) dengan menggunakan teknik-teknik lanjut model efek campur. Selain itu, validasi model seharusnya dilakukan sebelum penerapan model yang bersangkutan dengan mengumpulkan suatu dataset baru dari tegakan hutan yang sedang dikaji.

Kata kunci: Tapak-spesifik, model tinggi-diameter, fungsi regresi, hutan rawa gambut, Indonesia

\section{INTRODUCTION}

Reliable information on total tree height $(H)$ is fundamental of forest resource management and forest ecological studies. More specifically, $H$ as well as diameter (at breast height (DBH) or at a defined height above-ground level) are two essential tree parameters in forest inventory (Huang et al., 2000; Peng et al., 2001; Peng et al., 2004) and are commonly used in assessing site quality, site productivity, stand dynamics, succession, stand volume, growth and yield, and carbon budgets (e.g. Curtis, 1967; Stout and Shumway, 1982; Hara et al., 1991; Huang et al., 1992; Vanclay, 1992; Cobb et al., 1993; Huang and Titus, 1993; Huang et al., 2000; Peng et al., 2001; Peng et al., 2004; Sharma and Yin Zhang, 2004; Temesgen and Gadow, 2004; Akindele and LeMay, 2006; Sharma and Parton, 2007; Temesgen et al., 2007; Temesgen et al., 2008; Jiang and Li, 2010). In addition, these independent or compound variables in allometric equations are commonly used to predict the above-ground biomass (AGB) (e.g. Chave et al., 2005; Cole and Ewel, 2006; Litton and Kauffman, 2008; Verwer and Meer, 2010). $H$ is also a critical variable in process-based and hybrid (combination of empirical and processbased) models such as Formix 3-Q (Ditzer et al., 2000) and TRIPLEX1.0 (Zhou et al., 2005), which simulate the growth of forest stands.

A large number of previous studies relating to forest biomass estimation have noted that adding the $H$ variable can improve the performance of the allometric equation of the biomass. For this reason, many have formulated biomass equations that include $\mathrm{H}$ in addition to the DBH-only equation (e.g. Crow, 1978; Saldarriaga et al., 1988; Uhl et al., 1988; Brown et al., 1989; Overman et al., 1994; Brown, 1997; Nelson et al., 1999; Ketterings et al., 2001; Chave et al., 2005; Cole and Ewel, 2006; Fehrmann and Kleinn, 2006; Wang, 2006). Although adding H can only marginally increase the coefficient of determination $\left(\mathrm{R}^{2}\right)$, but the average deviation $(\bar{S}(\%))$ can be reduced significantly (e.g. $\sim 24 \%$ (Nelson et al., 1999)).

While the diameter of a tree can be measured quickly, easily and accurately, the measurement of $H$ is relatively complex, less accurate, time consuming, and expensive (Brown et al., 1989; Gower et al., 1999; Huang et al., 2000; Peng et al., 2001; Peng et al., 2004; Segura and Kanninen, 2005; Sharma and Parton, 2007). For these reasons, diameter is commonly measured for each tree during the forest inventory, whereas $\mathrm{H}$ is only measured for sampled trees (Huang et al., 2000; Peng et al., 2001; Peng et al., 2004; Chave et al., 2005; Castedo Dorado et al., 2006; Temesgen et al., 2008). A common way to acquire the missing $H$ information is by constructing a stand-specific allometric relationship between $H$ and DBH from sampled trees and then using the developed equation to predict the $\mathrm{H}$ for the rest of the trees being studied (Brown et 
al., 1989; Huang et al., 2000; Peng et al., 2001; Peng et al., 2004; Chave et al., 2005; Sharma and Parton, 2007; Jiang and Li, 2010).

The relationship between $H$ and diameter varies from stand to stand, and within the same stand the relationship varies over time (Curtis, 1967; Paulo et al., 2011). Stand to stand variation occurs due to the differences in site quality (Larsen and Hann, 1987; Wang and Hann, 1988), stand density (Temesgen and Gadow, 2004; Sharma and Parton, 2007) and stand age (VanderSchaaf, 2008). Variation over time within the same stand is caused by the relative position of the trees in a stand (Temesgen and Gadow, 2004) and the spatial distribution pattern (Aguirre et al., 2003; Zhang et al., 2004). Therefore, a conventional simple height-diameter $(H-D)$ model (e.g. Yamakura et al., 1986; Brown et al., 1989; Huang et al., 1992; Peng et al., 2001; Okuda et al., 2004; Nogueira et al., 2008) with DBH as the only predictor or independent variable has a local and temporal applicability to the stand from where the fit data was taken (Paulo et al., 2011).

A generalized $H-D$ model, with a wider range of geographical applicability, can be constructed by taking into account the stand variables that introduces the dynamics of each stand into the model (Temesgen and Gadow, 2004; Castedo Dorado et al., 2006; Paulo et al., 2011). These include basal area per hectare (ha) (Parresol, 1992; Sánchez et al., 2003; Sharma and Yin Zhang, 2004; Temesgen et al., 2007; Budhathoki et al., 2008), quadratic mean diameter (Sánchez et al., 2003), diameter distribution percentile (Fang and Bailey, 1998; Calama and Montero, 2004), stand density measures (Larsen and Hann, 1987; Sánchez et al., 2003; Calama and Montero, 2004; Sharma and Yin Zhang, 2004; Temesgen and Gadow, 2004; Castedo Dorado et al., 2006), relative tree position variables (Temesgen and Gadow, 2004; Temesgen et al., 2007), site quality variable (Larsen and Hann, 1987; Wang and Hann, 1988; Sharma and Yin Zhang, 2004), the random effects variable (Calama and Montero, 2004; Castedo Dorado et al., 2006; Jiang and Li,
2010) or including fixed dummy variables for regional effects (Huang et al., 2000; Calama and Montero, 2004; Peng et al., 2004).

$H-D$ relationships are commonly developed by applying non-linear biological growth functions such as Chapman-Richards (Richards, 1959), Weibull (Yang et al., 1978), exponential (Ratkowsky, 1990), modified logistic (Ratkowsky and Reedy, 1986), and Schnute (Schnute, 1981). Transformed and untransformed linear functions can be found in the paper by Curtis (1967). Advanced techniques are usually constructed by adding additional variables (e.g. stand variables) into the base model (e.g. Chapman-Richards function). Several studies have compared some linear and (or) non-linear models in the $H-D$ relationship studies (e.g. Curtis, 1967; Huang et al., 1992; Zhang, 1997; Fang and Bailey, 1998; Huang et al., 2000; Peng et al., 2001; Sánchez et al., 2003; Temesgen and Gadow, 2004).

Many studies have focused on modelling the relationships between $\mathrm{DBH}$ and $H$ for boreal forests (e.g. Huang et al., 1992; Peng et al., 2001; Temesgen and Gadow, 2004; Sharma and Parton, 2007; Temesgen et al., 2007; Temesgen et al., 2008) and for single species or plantation forests (e.g. Huang et al., 2000; Soares and Tomé, 2002; Sánchez et al., 2003; Peng et al., 2004; Castedo Dorado et al., 2006; Budhathoki et al., 2008; VanderSchaaf, 2008; Lee et al., 2009; Jiang and Li, 2010; Paulo et al., 2011), but comparatively very few studies have related to tropical forest trees (e.g. Yamakura et al., 1986; Brown et al., 1989; Thomas, 1996; Fang and Bailey, 1998; Bullock, 2000; Okuda et al., 2004; Nogueira et al., 2008; Djomo et al., 2010; Feldpausch et al., 2011). Furthermore, the relationships for peat swamp forest tree species, and especially for those in Indonesia, have not been widely published. Thus, the objective of this study was to develop site-specific $H-D$ models for tropical peat swamp forests using linearized and non-linear regression functions. 


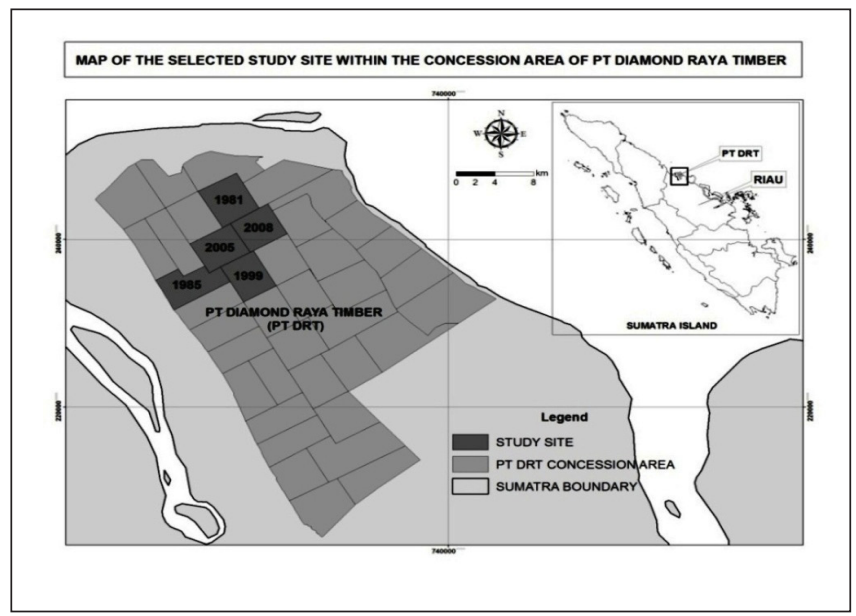

Figure 1. The selected study site within the forest concession area of PT. DRT

\section{MATERIAL AND METHOD}

\section{A. Study Site}

This study was conducted at the selected logging blocks within the concession area managed by PT. Diamond Raya Timber (PT. DRT) in Rokan Hilir District, Riau Province, Indonesia (Figure 1). The area is geographically located between $100^{\circ} 48^{\prime}-101^{\circ} 13^{\prime}$ East longitude and $1^{\circ} 49^{\prime}-2^{\circ} 18^{\prime}$ North latitude (Istomo, 2002). It is mainly covered by lowland peat swamp forest, in which the dominant commercial species are balam (Palaquium obovatum (Griffith) Enql.), meranti batu (Shorea uliginosa Foxw.), ramin (Gonystylus bancanus (Miq.) Kurz.), and terentang (Camnosperma coriaceum (Jack.) Hallier f. ex v. Steenis). This forest is also the important habitat for the endangered species of the Sumatran tiger (Panthera tigris sumatrae).

The topography of the area is flat with the elevation ranging about $0-8 \mathrm{~m}$ amsl (meter above mean sea level). In addition, the area is geologically dominated by peat dome along with alluvial and marine groups (Istomo, 2002). The dominant soil type is thick peat soil or histosol (hemic/sapric) with the depth of more than 3 m (Istomo, 2002; Wahyunto et al., 2005), while the minor ones are gley, alluvial and podzolic. Based on the Schmidt and Ferguson climate classification, the area is classified as A type with Q value of 10.1\% (Istomo, 2002). The average monthly rainfall ranges from 51.3 to $301.6 \mathrm{~mm}$ where the highest occurs in
November $(301.6 \mathrm{~mm}$ ) and the lowest in March $(51.3 \mathrm{~mm})$. Furthermore, the mean annual temperature ranges from 25 to $27^{\circ} \mathrm{C}$ and the relative humidity from $79 \%$ to $90 \%$.

\section{B. Data Collection}

The $H$ datasets were collected during the field campaign from August to December 2008. The $H$ data can be divided into three sets, according to how they were collected: (1) from the destructively sampled trees to support the generation of allometric biomass equations; (2) following the logging activity by the company, and including felled small trees as a result of logging activity; and (3) using destructive sampling for small trees harvested outside of the plots.

During the field campaign, 286 measurements of $\mathrm{DBH}$ and $H$ were taken from 38 tree species (listed in Appendix 1). The DBH was measured using a 100-cm diameter-measuring tape before the tree was harvested (for the destructive sampled trees) and after the tree was felled (for trees that had just been logged). Meanwhile, the $H$ of a sampled tree (after being felled/cut), including its stump, was measured based on its total length (cut tree + above-ground stumps) using a 50-m measurement tape. The DBH and $\mathrm{H}$ range for the sampled trees was $5.2-116.4 \mathrm{~cm}$ and 5.39-51.76 $\mathrm{m}$, respectively. 
Table 1. Type of $H$-D allometric equation models for $H$ estimation developed in this study

\begin{tabular}{|c|c|c|c|}
\hline Type & Model equation & Source & Model \\
\hline $\mathrm{I}$ & Linearized model & & \\
\hline & $\hat{H}=\exp (a+b \times \ln (D))$ & (Curtis, 1967) & 1 \\
\hline & $\hat{H}=\exp \left(a+b \times \ln (D)+c \times(\ln (D))^{2}\right)$ & (Curtis, 1967) & 2 \\
\hline II & Non-linear model & & \\
\hline $\begin{array}{l}\text { Chapman- } \\
\text { Richards }\end{array}$ & $\hat{H}=1.3+a(1-\exp (-b \times D))^{c}$ & $\begin{array}{l}\text { (Richards, 1959; } \\
\text { Huang et al., 1992) }\end{array}$ & 3 \\
\hline Weibull & $\hat{H}=1.3+a\left(1-\exp (-b \times D)^{c}\right)$ & $\begin{array}{l}\text { Yang et al., 1978; } \\
\text { Huang et al., 1992) }\end{array}$ & 4 \\
\hline Schnute & $\hat{H}=\left[1.3^{b}+\left(c^{b}-1.3^{b}\right) \times\left(\frac{1-\exp \left(-a\left(D-D_{0}\right)\right)}{1-\exp \left(-a\left(D_{2}-D_{0}\right)\right)}\right)\right]^{b}$ & $\begin{array}{l}\text { (Schnute, 1981; } \\
\text { Huang et al., 1992) }\end{array}$ & 5 \\
\hline Exponential & $\hat{H}=1.3+a \times \exp \left(\frac{b}{D+c}\right)$ & $\begin{array}{l}\text { (Ratkowsky, 1990; } \\
\text { Huang et al., 1992) }\end{array}$ & 6 \\
\hline $\begin{array}{l}\text { Modified } \\
\text { Logistic }\end{array}$ & $\hat{H}=1.3+\left(\frac{a}{1+b^{-1} \times D^{-c}}\right)$ & $\begin{array}{l}\text { (Ratkowsky and } \\
\text { Reedy, 1986; } \\
\text { Huang et al., 1992) }\end{array}$ & 7 \\
\hline
\end{tabular}

Notes: $\hat{H}$ is the estimated total tree height $(\mathrm{m})$, exp is $e$ raised to the particular $i^{t h}$ power, $\ln$ is natural logarithm, $D$ is the diameter at breast height or $\mathrm{DBH}(\mathrm{cm}), 1.3$ is a constant used to account that $D$ is measured at $1.3 \mathrm{~m}$ (in height from the ground), and $a, b$ and $c$ are the regression coefficients. For Model $5, D_{0}=0.0 \mathrm{~cm}$ and $D_{2}=100.0 \mathrm{~cm}$

\section{Data Analysis}

\section{Regression models}

Type I (linearized) and Type II (non-linear) regression models were used to develop the $H-D$ equations. The type I model consisted of two $H-D$ models, whilst the type II model comprised of five $H-D$ models. These nonlinear models were selected based on the study of Huang et al. (1992) that reviewed 20 non-linear $H-D$ models. The mathematical formulation for each model is listed in Table 1. The data analysis for constructing the models was carried out using the JMP® 8.0.1 statistical package developed by SAS Institute Inc. (SAS Institute Inc., 2009).

\section{Model selection}

The model selection was based on six statistical parameters, where four were explained by Parresol (1999), comprising: (1) the fit index $(F I),(2)$ the standard error of estimate in actual unit $\left(\mathrm{S}_{\mathrm{e}}\right),(3)$ the coefficient of variation $(\mathrm{CV})$ in percent, and (4) the corrected mean percent standard error of prediction $(\bar{S}(\%))$ or average (unsigned) deviation (Nelson et al., 1999; Basuki et al., 2009). The fifth parameter is bias (e.g. Temesgen and Gadow, 2004; Jiang and Li, 2010) and the sixth is the Akaike's Information Criterion/AIC (Akaike, 1974). The best model will have the lowest $A I C$ value. The equations used to calculate those statistical parameters are presented in Table 2 . 
Table 2. The equations used to calculate the six statistical parameters

\begin{tabular}{|c|c|}
\hline Statistical parameter & Equation \\
\hline$F I=1-\left(\frac{R S S}{T S S}\right)$ & (1) \\
\hline$R S S=\sum_{i=1}^{n}\left(Y_{i}-\hat{Y}_{i}\right)^{2}$ & (2) \\
\hline$T S S=\sum_{i=1}^{n}\left(Y_{i}-\bar{Y}\right)^{2}$ & (3) \\
\hline$S_{e}=\sqrt{\frac{R S S}{(n-p)}}$ & (4) \\
\hline$C V=\left(\frac{S_{e}}{\bar{Y}}\right) \times 100$ & (5) \\
\hline $\bar{S}(\%)=\frac{100}{n} \sum_{i=1}^{n} \frac{\left|Y_{i}-\hat{Y}_{i}\right|}{Y_{i}}$ & (6) \\
\hline$B=\left(\frac{\sum_{i=1}^{n}\left(Y_{i}-\hat{Y}_{i}\right)}{n}\right)$ & (7) \\
\hline$A I C=C \ln \left(\frac{J_{e}}{C}\right)+2 p$ & (8) \\
\hline
\end{tabular}

Notes:

FI is the fit index, RSS is the residual sum of squares, TSS is the total sum of squares, $Y_{i}$ is the observed data of the $i^{\text {th }}$ sample, $\bar{S}(\%)$ is the estimated data of the $i^{\text {th }}$ sample, $\bar{S}(\%)$ is the arithmetic mean of the observed data, $n$ is the number of sample observations, $S$ is the standard error of estimate in actual unit, $p$ is the number of model parameters, including intercept, $C V$ is the coefficient of variation, $\bar{S}(\%)$ is the corrected mean percent standard error of prediction, $B$ is the bias, $A I C$ is the Akaike's Information Criterion, $C$ is the number of observed data, $\ln$ is natural logarithm, and $S S_{e}$ is the residual sum of squares.

\section{Model prediction}

For the linearized models, the $H$ and $D$ data were transformed according to the natural logarithm during the model construction. This process introduced a systematic bias of the predicted heights when they were backtransformed to the actual unit, where the estimates usually underestimated the actual values (Chave et al., 2005). For this reason, the predicted height was multiplied by a $C F$ as suggested by Snowdon (1991). The CF ratio estimator formula is mathematically written as in equation (9).

$$
C F_{S D}=\left(\frac{\frac{\sum_{i=1}^{n} Y_{i}}{n}}{\frac{\sum_{i=1}^{n} \hat{Y}_{i}}{n}}\right)
$$

where $\mathrm{CF}_{\mathrm{SD}}$ is the correction factors described by Snowdon (1991), $Y_{\mathrm{i}}$ is the observed data of the ith sample, $\hat{Y}_{i}$ is the estimated data of the $i^{\text {th }}$ sample, and $n$ is the number of sample.

\section{RESULT AND DISCUSSION}

\section{A. Developing Site-specific H-D Allometric Models for Peat Swamp Forests}

In this study, seven $H-D$ models were developed from 286 destructively sampled mixed tree species in tropical peat swamp forest. Two models were constructed following the linearized function, while five models were developed using the non-linear functions. The summaries of the regression coefficients and the comparison parameters are presented in Table 3. The scatter plots of studentized residuals and predicted heights for all models showed homogenous variance over the full range of the predicted values and no systematic pattern in the variation of the residuals (see Appendix 2). The scatter plot of $H$ against $D$ is presented in Figure 2. The distribution pattern followed the concave shaped curve. For the linearized models (generated by transforming the datasets based on natural logarithmic - $\ln (H)$ and $\ln (D)$ ), the second order polynomial model (Model 2) performed better than Model 1. The difference between Model 1 and Model 2 was prominent. Adding the square of $\ln (D)$ to the 


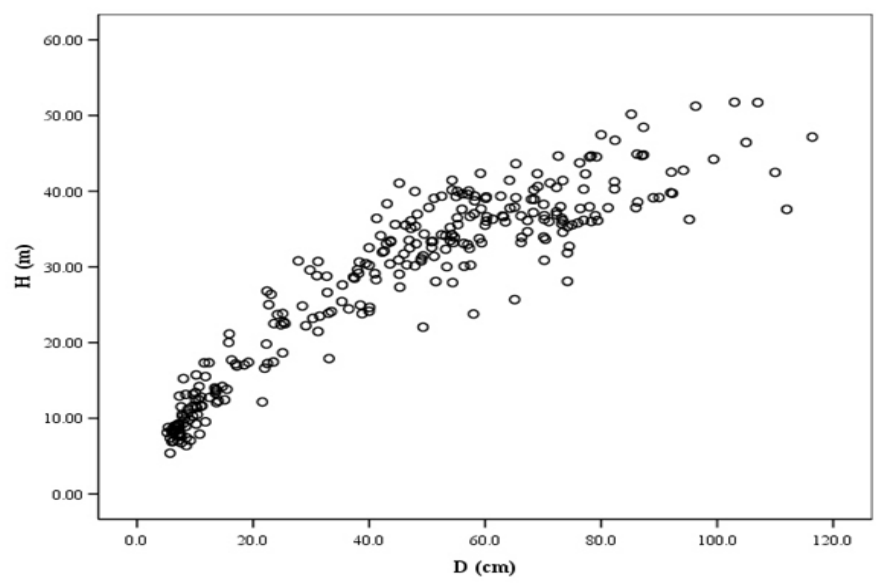

Figure 2. Scatter plot of $\mathrm{H}(\mathrm{m})$ against $\mathrm{D}(\mathrm{cm})$

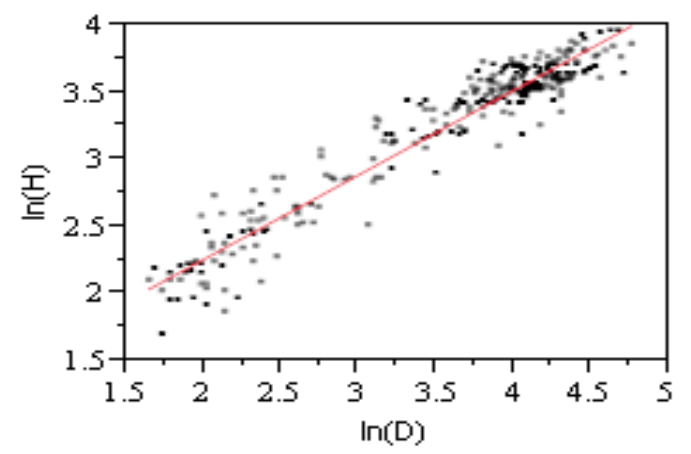

(a)

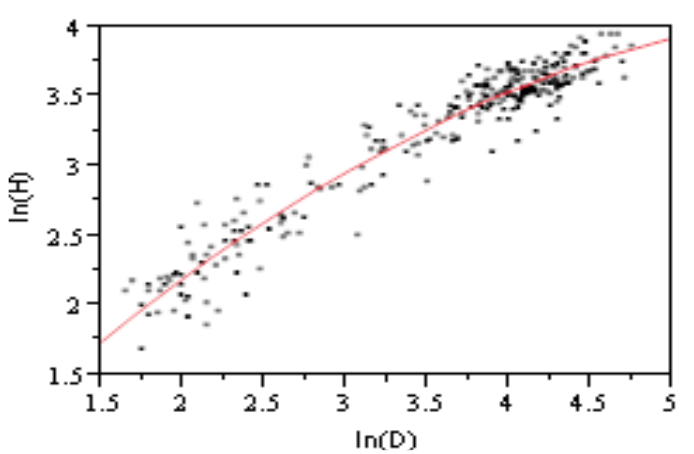

(b)

Figure 3. Scatter plots of transformed natural base logarithmic of $H(\ln (\mathrm{H}))$ and $\mathrm{DBH}(\ln (D))$. The curves were produced using (a) Model 1-linear and (b) Model 2-second order polynomial

model improved the index fit (corresponding to $\mathrm{R}^{2}$ ) by $2.3 \%$ and reduced the standard error (equivalent to RMSE), $C V$ and $\bar{S}(\%)$ by $11.3 \%, 11.5 \%$ and $6.7 \%$, respectively. However, incorporating an extra predictor variable to the model led to an increase in bias (mean residual) of $166.7 \%$. Nonetheless, the actual values were relatively small and negligible (see details in Table 3). AIC proved that Model 2 was better than Model 1 indicated by the smaller value of AIC. The scatter plots of Model 1 and Model 2 are presented in Figure 3.

For the non-linear models, Model 6 (exponential function) outperformed the other models. Model 6 had slightly better $C V$, $\bar{S}(\%)$ and $A I C$ values (see Table 3$)$. However, in general, all of the non-linear models fitted the data equally well. Based on the FI values, all the models explained approximately $91 \%$ of the variations in the $H$ caused by changing the $\mathrm{DBH}$ with the Se of about $3.6 \mathrm{~m}$. The $\mathrm{CV}$ values for the non-linear models were approximately $12.7 \%$ and the $\bar{S}(\%)$ values were less than $11 \%$. Model 5 (Schnute function) and Model 6 had lower bias compared to the other models (close to zero), while Model 4 (Weibull function) had the highest bias. Nevertheless, the bias values for all models were relatively small and negligible. The AIC values ranged from 733.0 to 734.5 . In this regard, Model 3 (Chapman-Richards) had the highest $A I C$ value. In general, the nonlinear models had similar performances with the second order polynomial function (Model 2). 
Table 3. Regression coefficients and comparison parameters for each $H$-D model

\begin{tabular}{|c|c|c|c|c|c|c|c|c|c|c|}
\hline \multirow{2}{*}{ Model } & \multicolumn{3}{|c|}{ Coefficient } & \multicolumn{6}{|c|}{ Comparison Parameters } & \multirow{2}{*}{$C F$} \\
\hline & Symbol & Value & SE & FI & Se & $C V$ & $\bar{S}(\%)$ & Bias & $A I C$ & \\
\hline 1. & $\begin{array}{l}a \\
b\end{array}$ & $\begin{array}{l}0.9891 \\
0.6300\end{array}$ & $\begin{array}{l}0.0383 \\
0.0106\end{array}$ & 0.89 & 4.06 & 14.39 & 11.87 & 0.0024 & 803.6 & 1.0046 \\
\hline 2. & $\begin{array}{l}a \\
b\end{array}$ & $\begin{array}{l}0.1209 \\
1.2198\end{array}$ & $\begin{array}{l}0.1427 \\
0.0943\end{array}$ & 0.91 & 3.60 & 12.74 & 11.07 & 0.0064 & 736.0 & 1.0079 \\
\hline 3. & $\begin{array}{l}c \\
a \\
b \\
c\end{array}$ & $\begin{array}{c}-0.0920 \\
46.7505 \\
0.0218 \\
0.9313\end{array}$ & $\begin{array}{l}0.0146 \\
1.9823 \\
0.0030 \\
0.0635\end{array}$ & 0.91 & 3.59 & 12.71 & 10.96 & -0.0036 & 734.5 & NC \\
\hline 4. & $\begin{array}{l}a \\
b \\
c\end{array}$ & $\begin{array}{c}47.3152 \\
0.0276 \\
0.9466\end{array}$ & $\begin{array}{l}2.4465 \\
0.0030 \\
0.0478\end{array}$ & 0.91 & 3.59 & 12.70 & 10.96 & 0.0152 & 734.3 & $\mathrm{NC}$ \\
\hline 5. & $\begin{array}{l}a \\
b\end{array}$ & $\begin{array}{c}0.0214 \\
1.0987 \\
431383\end{array}$ & $\begin{array}{l}0.0032 \\
0.0937 \\
0.6528\end{array}$ & 0.91 & 3.59 & 12.70 & 10.96 & 0.0003 & 734.4 & $\mathrm{NC}$ \\
\hline 6. & $\begin{array}{l}c \\
a \\
b\end{array}$ & $\begin{array}{c}43.1383 \\
58.4239 \\
-36.7363\end{array}$ & $\begin{array}{l}2.2809 \\
3.6822\end{array}$ & 0.91 & 3.58 & 12.67 & 10.89 & -0.0006 & 733.0 & $\mathrm{NC}$ \\
\hline 7. & $\begin{array}{l}c \\
a \\
b \\
c\end{array}$ & $\begin{array}{c}10.9102 \\
59.5266 \\
0.0176 \\
1.0690\end{array}$ & $\begin{array}{l}1.8363 \\
4.6786 \\
0.0023 \\
0.0721\end{array}$ & 0.91 & 3.58 & 12.68 & 10.95 & 0.0093 & 733.2 & NC \\
\hline
\end{tabular}

Notes: $S E=$ standard error of the coefficient, FI = Fit Index, $S_{e}=$ Standard error in actual unit, $C V=$ Coefficient of Variation, $\bar{S}(\%)=$ Average deviation, $A I C=$ Akaike's Information Criterion, $C F=$ correction factor, NC $=$ Not Corrected

Based on the $H-D$ curves for the nonlinear models (Figure 4), it was observed that the curves were sigmoidal or S-shaped, which is typical of the general pattern of the tree's biological growth. However, the inflection points were not apparent. It is also important to note that the five non-linear models fitted to the same dataset produced different asymptote coefficients (indicated by the coefficient $\mathrm{a}$ in Table 3, with the exception of Schnute function of Model 5 in which the asymptotic coefficient was approximate to the coefficient c). In general, two asymptote values can be grouped from Table 3: (1) those close to $50 \mathrm{~m}$ values, being the Chapman-Richards, Weibull and Schnute functions (Model 3, 4 and 5), and (2) those close to $60 \mathrm{~m}$ values, being the exponential and modified logistic functions (Model 6 and 7). Model 5 (Schnute function) had the lowest asymptote value, whereas Model 7 (modified logistic function) had the highest one.

Figure 5 provides a graphical visualization of the curve comparison among the models. For lower DBH values (approximately up to 25 $\mathrm{cm}$ ), all the models tended to generate relatively similar estimates of $H$. Where the $\mathrm{DBH}$ ranged from $25 \mathrm{~cm}$ to $65 \mathrm{~cm}$, Model 1 produced lower estimates of $H$, while other models resulted in similar values of $H$. Where the $\mathrm{DBH}$ exceeded $65 \mathrm{~cm}$, Model 1 deviated increasingly from the other models. Model 2 tended to give slightly larger estimates than the non-linear models at DBH above $100 \mathrm{~cm}$. However, there was no apparent difference in height estimates among the non-linear models as can be observed from Figure 5.

The developed models had generally low $\bar{S}(\%)$ less than $16 \%$ for all DBH classes (Table 4). All the site-specific equations tended to have a higher $\bar{S}(\%)$ value for smaller $\mathrm{DBH}$ classes. For DBH class, less than $10 \mathrm{~cm}$, the $\bar{S}(\%)$ ranged from $14.7 \%$ to $15.9 \%$, while for $\mathrm{DBH}$ class of $10-30 \mathrm{~cm}$, the $\bar{S}(\%)$ ranged from $14.0 \%$ to $14.5 \%$. These $\bar{S}(\%)$ values decreased 


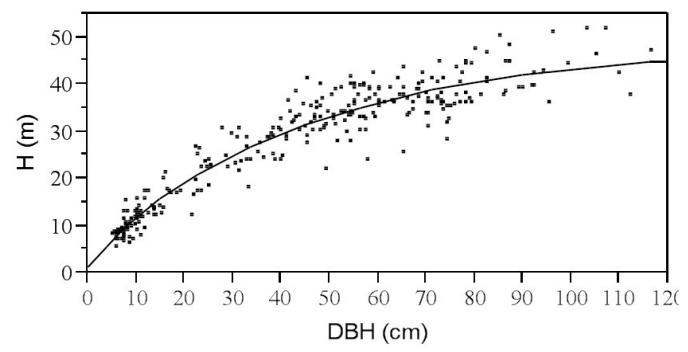

(a)

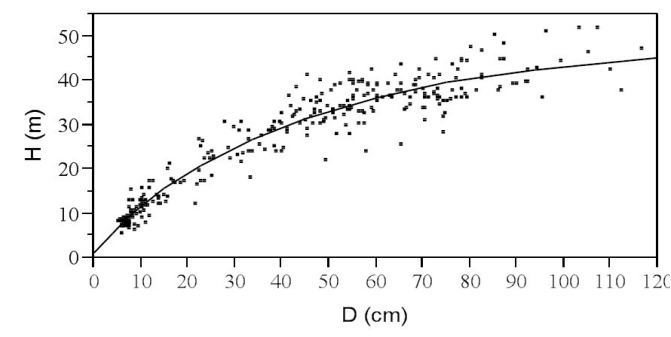

(b)

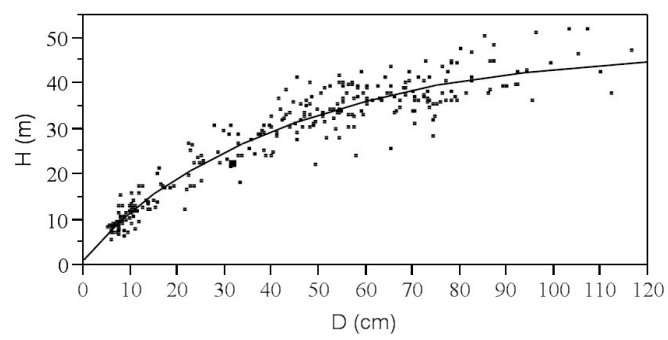

(c)

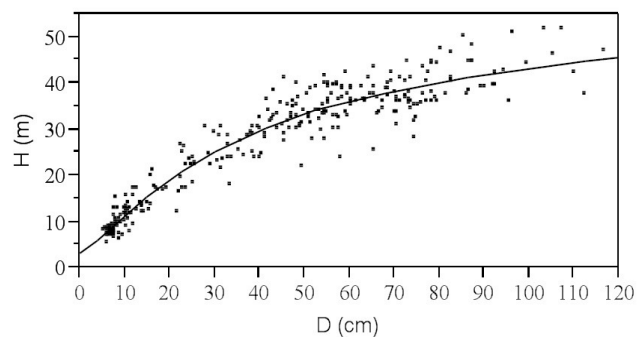

(d)

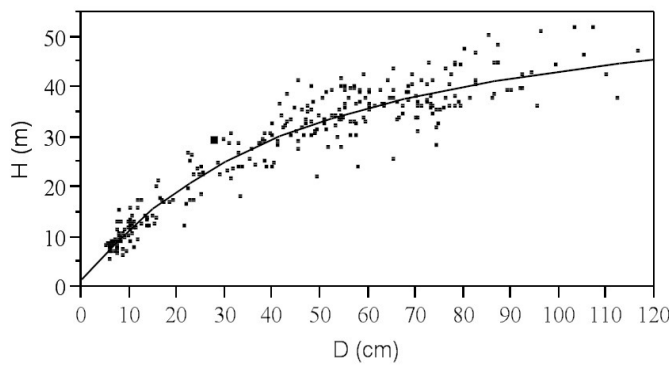

(e)

Figure 4. Scatter plots of $H(\mathrm{~m})$ and $D(\mathrm{~cm})$. The curves were produced by: (a) Model 3-Chapman-Richards; (b) Model 4-Weibull; (c) Model 5-Schnute; (d) Model 6-Exponential; and (e) Model 7-Modified logistic

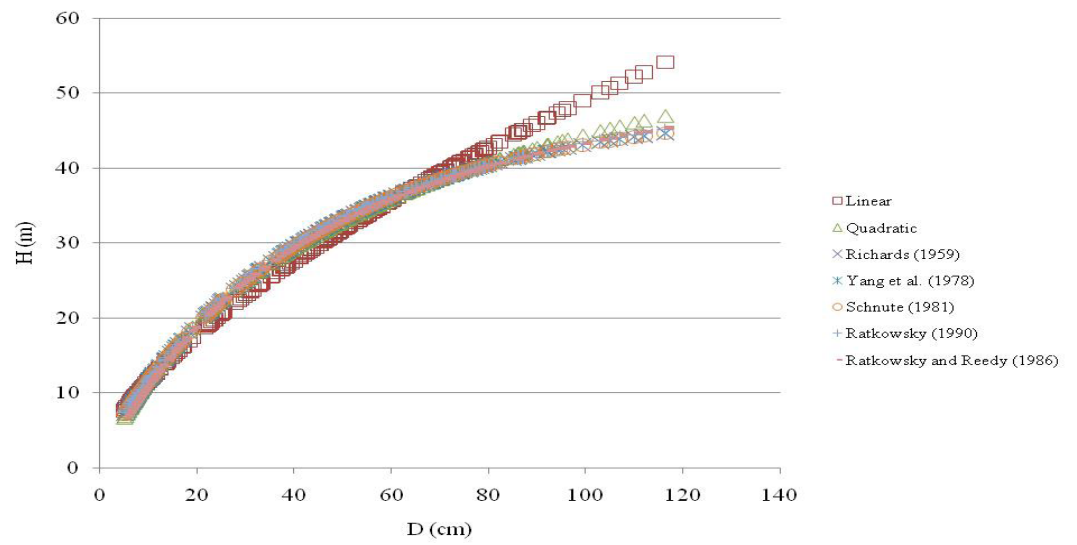

Figure 5. Predicted $H$ using the seven $H-D$ models (square: linear, triangle: quadratic, cross:

Chapman-Richards, star: Weibull, plus: exponential, and minus: modified logistic)

for larger $\mathrm{DBH}$ classes with common values of less than 11\%, except for Model 1 (11.38\% and $14.99 \%$ at DBH classes of $70-90 \mathrm{~cm}$ and more than $90 \mathrm{~cm}$, respectively). In general, Model 6 provided the most precise estimate of $\mathrm{H}$ within lower DBH classes $(\leq 30 \mathrm{~cm})$ and Model 7 produced the most precise prediction at larger DBH classes $(>50 \mathrm{~cm})$. For DBH class of $30-$ $50 \mathrm{~cm}$, Model 3 and Model 5 gave the same $\bar{S}(\%)$ value $(10.05 \%)$. However, this value 
Table 4. A summary of the $\bar{S}(\%)$ per DBH classes (cm) for each H-D model

\begin{tabular}{ccccccc}
\hline \multirow{2}{*}{ Model } & \multicolumn{7}{c}{$\begin{array}{c}\text { Mean } \bar{S}(\%) \\
\text { PBH classes }(\mathrm{cm})\end{array}$} \\
\hline & $\varnothing<=10$ & $10<\varnothing<=30$ & $30<\varnothing<=50$ & $50<\varnothing<=70$ & $70<\varnothing<=90$ & $\varnothing>90$ \\
\hline Model 1 & 15.91 & 14.07 & 10.82 & 8.41 & 11.38 & 14.99 \\
Model 2 & 15.00 & 14.47 & 10.14 & 8.14 & 9.90 & 8.82 \\
Model 3 & 14.89 & 14.16 & 10.05 & 8.16 & 9.82 & 8.83 \\
Model 4 & 14.89 & 14.18 & 10.06 & 8.15 & 9.79 & 8.81 \\
Model 5 & 14.88 & 14.18 & 10.05 & 8.16 & 9.81 & 8.82 \\
Model 6 & 14.70 & 14.00 & 10.08 & 8.16 & 9.72 & 8.75 \\
Model 7 & 14.75 & 14.30 & 10.10 & 8.14 & 9.71 & 8.69 \\
\hline
\end{tabular}

Notes:

$\varnothing=\mathrm{DBH}(\mathrm{cm})$ and $n=$ number of sampled tree

was relatively similar to the ones produced by Model 4 and Model 6, with those being 10.06\% and $10.08 \%$, respectively.

\section{B. H-D Models for Tropical Peat Swamp Forest Tree Species}

$H$ is an important tree parameter for many forestry related applications not only for forest resource management but also for forest ecological studies. Measuring $\mathrm{H}$ of a standing tree in a dense forest stand, however, is challenging, time consuming and expensive (Brown et al., 1989; Gower et al., 1999; Huang et al., 2000; Peng et al., 2001; Brown, 2002; Peng et al., 2004; Segura and Kanninen, 2005; Sharma and Parton, 2007), especially in tropical forests with many features, like multi-species, multi-storey and multi-age. In addition, direct measurement of $\mathrm{H}$ is usually inaccurate because the top of the tree often cannot be easily observed and measured (Brown, 2002). As a result, $H$ is only collected for sampled trees, while the DBH is collected for all the trees in the measurement plots during the regular forest inventory (Huang et al., 2000; Peng et al., 2001; Peng et al., 2004; Chave et al., 2005; Castedo Dorado et al., 2006; Temesgen et al., 2008). In tropical peat swamp forests, collecting accurate $H$ data is almost impossible without felling the tree. This is because of the terrain condition that was almost entirely inundated and the multi-layer of the forest canopy makes it difficult to observe the top of the tree to be measured. Therefore, models or functions that relate $H$ to $\mathrm{DBH}$ have a crucial role in providing estimates of the missing information of the $\mathrm{H}$ of the trees (Brown et al., 1989; Huang et al., 2000; Peng et al., 2001; Peng et al., 2004; Chave et al., 2005; Sharma and Parton, 2007; Jiang and $\mathrm{Li}, 2010)$, considering the strong correlation between these two tree parameters.

Although many $H-D$ models are available for boreal forest tree species (Huang et al., 1992; Sharma and Parton, 2007; Temesgen et al., 2008) and for single species or plantation forests (e.g. Soares and Tomé, 2002; Peng et al., 2004; Castedo Dorado et al., 2006; VanderSchaaf, 2008; Lee et al., 2009; Jiang and Li, 2010; Paulo et al., 2011), but relatively few models are available for tropical forest tree species (e.g. Yamakura et al., 1986; Brown et al., 1989; Fang and Bailey, 1998; Bullock, 2000; Okuda et al., 2004; Djomo et al., 2010; Feldpausch et al., 2011). In addition, currently there are no publications available on $H-D$ models for peat swamp forests, specifically in Indonesia. Considering that $H$ can improve the performance of allometric biomass equations (Brown et al., 1989; Brown, 2002), this study will contribute to increase the accuracy of biomass assessment in addition to the forest management's purpose. 
The results of this study indicated that the non-linear models outperform the linearized models. Model 1, which is the simplest model with one predictor, has the poorest model performance with an FI of only 0.89 (corresponding to a 0.93 of $\mathrm{R}^{2}$ in linear regression), an $\mathrm{S}_{\mathrm{e}}$ of $4.1 \mathrm{~m}$ and an $\bar{S}(\%)$ of $11.9 \%$. However, the $\mathrm{R}^{2}$ of Model 1 was much higher than that of the equation from Brown et al. (1989), which was only 0.61 . The lower $\mathrm{R}^{2}$ value of the $H-D$ model presented by Brown et al. (1989) can be attributed to the high variability of the collected $H-D$ dataset, which came from a wide range of geographical area (Venezuela, Puerto Rico and Papua New Guinea), considering that the $H-D$ relationship varies from stand to stand and within the same stand over time (Curtis, 1967; Temesgen and Gadow, 2004; Temesgen et al., 2007; Temesgen et al., 2008; Paulo et al., 2011) and is influenced by the conditions of the local environment (Peng et al., 2004). The second order polynomial function (Model 2) resulted in a better performance, with the FI of 0.91 , the $\mathrm{S}_{\mathrm{e}}$ of $3.6 \mathrm{~m}$ and the $\bar{S}(\%)$ of $11.1 \%$. In general, this model had a similar performance to the non-linear models developed in this study. However, previous studies did not recommend the polynomial equations for growth and yield or $H$-D relationship because they are devoid of any biological interpretation (Zeide, 1993) and do not have meaningful parameters from a forestry perspective (Lei and Zhang, 2004).

Many non-linear theoretical models (e.g. the Chapman-Richards, the Weibull, the Schnute, the exponential and the modified logistic) have been used to model $H$-D relationships (e.g. Huang et al., 1992; Zhang, 1997; Fang and Bailey, 1998; Peng et al., 2001) because theoretical models have an underlying hypothesis associated with the cause or the function of the phenomenon described by the response variable (Vanclay, 1994). However, there is no general agreement on the best non-linear base model for $H-D$ relationship studies.

In this regard, the Chapman-Richards growth function has been employed more often than any other models (e.g. Peng et al., 2004; Sharma and Yin Zhang, 2004; Pilli et al., 2006; Sharma and Parton, 2007; Temesgen et al., 2008), because of its accuracy (Zeide, 1993; Lei and Zhang, 2004). In this study, the results from model comparison parameters suggested that all five non-linear models fitted the $H-D$ dataset equally well (Table 3 ) with the FI, the $\mathrm{S}_{\mathrm{e}}$ and the $\bar{S}(\%)$ values being $0.91,3.58-3.59$ $\mathrm{m}$ and $10.89 \%-10.96 \%$, respectively. This is consistent with the findings reported by Huang et al. (1992) for major Alberta tree species, by Zhang (1997) for ten tree species in inland Northwest of the United States, by Peng et al. (2001) for nine tree species of Ontario's boreal forest, and by Krisnawati et al. (2010) for Acacia mangium plantation forest in South Sumatra, Indonesia. Based on the model comparison parameters, the Chapman-Richards equation (Model 3) resulted in the poorest performance compared to other models but gave a lower bias than the Weibull (Model 4) and modified logistic functions (Model 7). In general, however, the differences among the models were trivial.

In developing the models, reasonable biological criteria in addition to the datarelated criteria in the model selection needed to be considered (Yuancai and Parresol, 2001). In this regard, the model should represent the biological process of tree growth. From a biological point of view, a height curve should exhibit a sigmoid or S-shaped pattern and possess three properties: (1) monotonic increment, (2) inflection point, and (3) asymptotic value (Parresol, 1992; Yuancai and Parresol, 2001). In this study, all five non-linear models produced $H-D$ curves that followed a sigmoid or S-shaped pattern as presented in Figure 4. However, the inflection points were not clearly visible. This was probably because the $H-D$ dataset did not contain $\mathrm{DBH}$ values lower than $5 \mathrm{~cm}$, which constitutes the early stage of tree growth as suggested by Parresol (1999), Yuancai and Parresol (2001) and Pilli et al. (2006). Yuancai and Parresol (2001) indicated that the five models suggested by Huang et al. (1992), which were used in this study, produced 
S-shaped curves with inflection points. The Chapman-Richards (Model 3), Weibull (Model 4) and Schnute (Model 5) equations had relatively similar asymptotes (close to $50 \mathrm{~m}$ ). The same findings were reported by Huang et al. (1992), Zhang (1997) and Peng et al. (2001). On the other hand, the exponential (Model 6) and the modified logistic (Model 7) functions had similar asymptotes of close to $60 \mathrm{~m}$. Huang et al. (1992) reported the same finding for major Alberta tree species. The asymptotic value of close to $60 \mathrm{~m}$ is more realistic for the study area considering that the maximum height in the dataset was $51.76 \mathrm{~m}$ (Appendix 1).

Paulo et al. (2011) suggested that the $H-D$ functions should pass through the point ( $D=0, H=1.30 \mathrm{~m})$ to prevent negative height estimates for small trees and/or to guarantee a good estimation for small trees. In addition, it is important to meet a theoretical assumption that tree $\mathrm{DBH}$ should be zero when $\mathrm{H}$ is 1.30 $m$ because the DBH is defined as the tree diameter at breast height or $1.30 \mathrm{~m}$ from the ground (Fang and Bailey, 1998). Based on the extrapolation, all the non-linear models passed through the point of diameter-height $(0,1.3)$ with the exception of the exponential function of Model 6 (0, 3.31). Soares and Tomé (2002) found poor height predictions for young stands from the equation that not restricted to the point of diameter-height $(0,1.3)$. Therefore, Model 7 (the modified logistic) is better suited for estimating $\mathrm{H}$ in peat swamp forests, although it is the second best equation after Model 6 in terms of the statistical parameters. Huang et al. (2000) found the modified logistic function to be the best model for white spruce in boreal forests.

\section{The Applicability of The Developed Models and The Possible Improvements}

There are two types of $H-D$ equations based on their applications: (1) local and (2) generalized (Soares and Tomé, 2002). The local equations are normally only developed based on $\mathrm{DBH}$ and can be applied to the stand where the dataset was collected, while the generalized or regional equations are constructed using $\mathrm{DBH}$ and other stand variables and can be applied at the regional level. Considering that the developed models in this study used only $\mathrm{DBH}$ as a predictor, their application is restricted to the study area where the dataset was gathered. In addition, it is relatively safe to perform an extrapolation for the non-linear $H-D$ models because $H$ normally has a maximum during its life span which is approximated by the asymptote coefficients (Yuancai and Parresol, 2001). Therefore, $H$ will not increase after the maximum height is reached, although the $\mathrm{DBH}$ will increase continuously. Thus, using the models to estimate $H$ for larger DBH beyond the validity range will not result in large errors. For example, $H$ extrapolated from a $\mathrm{DBH}$ of 200, 250 and $300 \mathrm{~cm}$ was 47.5, 47.9 and $48.0 \mathrm{~m}$, respectively (for Model 3-Chapman-Richards), 47.9, 48.3 and $48.5 \mathrm{~m}$, respectively (for Model 4-Webull), 47.6, 48.0 and $48.2 \mathrm{~m}$, respectively (for Model 5-Schnute), 50.4, 52.1 and $53.2 \mathrm{~m}$, respectively (for Model 6-exponential), and 51.0, 52.8 and $54.1 \mathrm{~m}$, respectively (for Model 7 -modified logistic). These ranges of $H$ values are still realistic for peat swamp forest tree species (see Appendix 1). $H$ should not be extrapolated using the linear models because these models do not possess asymptotic values. Therefore, based on the linear models, $H$ will increase when the $\mathrm{DBH}$ increases without any limit.

In this study, the $H-D$ models were developed from 38 tree species with variable $H-D$ characteristics. For example, Cratoxylum arborescens and Tetramerista glabra species tended to have lower tree heights for the same DBH, while Shorea uliginosa and Gonystylus bancanus tended to have greater heights. For a DBH of 95.2 and $112.0 \mathrm{~cm}, H$ for $C$. arborescens were 36.27 and $37.60 \mathrm{~m}$, respectively, which were significantly lower than those of other species with typical heights of $39.00-51.00 \mathrm{~m}$. $H$ for $T$. glabra with DBH of 58.0, 65.1 and $74.2 \mathrm{~cm}$ were 23.76, 25.68 and $28.09 \mathrm{~m}$, respectively, which were much lower than those of other species with common heights of 33.00-41.00 m. For 
the DBH of 41.3 and $43.1 \mathrm{~cm}$, the total tree heights for S. uliginosa were 36.41 and 38.35 $\mathrm{m}$, respectively, which were significantly taller than those of other species with typical heights of $28.00-33.00 \mathrm{~m}$. The total tree height for G. bancanus with $\mathrm{DBH}$ of $47.9 \mathrm{~cm}$ was 39.97 $\mathrm{m}$, which was much taller than those of other species with common heights of 30.00-36.00 $\mathrm{m}$. As a consequence, these species had larger studentized residuals, more than 2.5 standard deviations (Appendix 2). Thus, grouping the species based on their $H-D$ characteristics and then constructing $H-D$ models for each species group may improve the model performance.

The improvement in the $H-D$ models can also be achieved by incorporating stand variables as reported by various authors from previous studies. Such variables may include basal area per ha (Parresol, 1992; Sánchez et al., 2003; Sharma and Yin Zhang, 2004; Temesgen et al., 2007; Budhathoki et al., 2008), quadratic mean diameter (Sánchez et al., 2003), diameter distribution percentile (Fang and Bailey, 1998; Calama and Montero, 2004), stand density measures (Larsen and Hann, 1987; Sánchez et al., 2003; Calama and Montero, 2004; Sharma and Yin Zhang, 2004; Temesgen and Gadow, 2004; Castedo Dorado et al., 2006), relative tree position variables (Temesgen and Gadow, 2004; Temesgen et al., 2007), and site quality variables (Larsen and Hann, 1987; Wang and Hann, 1988; Sharma and Yin Zhang, 2004) or fixed dummy variables can be included for regional effects (Huang et al., 2000; Calama and Montero, 2004; Peng et al., 2004). The inclusion of these stand variables improved $\mathrm{H}$ estimates and the applicability of the models as long as the required stand variables were available (Temesgen et al., 2007; Jiang and Li, 2010). However, when the additional stand variables are unavailable for a forest stand being studied, the application of the generalized model becomes limited (Jiang and Li, 2010).

Recent studies reported that the application of mixed-effect modelling in the development of $H-D$ models improved the performance and the predictive ability of the models (Calama and Montero, 2004; Castedo Dorado et al., 2006; Sharma and Parton, 2007; Budhathoki et al., 2008; Temesgen et al., 2008; Lee et al., 2009; Jiang and Li, 2010; Paulo et al., 2011). In contrast to traditional regression techniques, mixed-effect models allow fixed and random parameters to be estimated simultaneously, providing consistent estimates of the fixed parameters and their standard errors (Jiang and Li, 2010). In addition, these models also explain the correlation structure of the data and provide realistic variance estimates for stochastic simulation and for modelling natural variability (Temesgen et al., 2008). The inclusion of random parameters enables the models to capture more variation among and within stands (Jiang and Li, 2010). By calibrating the random parameters through a sub-sample of tree height measurement from a particular forest stand, the mixed-effect model can be used to predict tree heights from a new stand (Temesgen et al., 2008; Jiang and Li, 2010). Therefore, the application of mixed-effect models will also improve the geographical applicability of the H-D models.

\section{CONCLUSION}

In this study, seven $H-D$ models were developed based on the application of linearized and non-linear regression functions. The non-linear models outperformed the linearized models based on the statistical parameters and the biological criteria. All five non-linear models performed equally well and the differences between them were trivial. However, the modified logistic function (Model 7) is recommended for estimating $H$ in the study area as it has comparable model performances to the exponential function (Model 6) and passed the diameter-height point of $(0,1.3)$. Further improvements, however, are needed to improve the accuracy, the predictive ability and the geographical applicability of the model by grouping the species, adding stand variables and (or) using advanced techniques of mixed-effect modelling. In addition, model validation should be carried out prior to their 
application by collecting a new dataset from the forest being studied.

\section{ACKNOWLEDGEMENT}

The author is very grateful to Prof. Richard Lucas, Assoc. Prof. Cris Brack and Dr. Bruce Doran for their invaluable comments and supports. The author is also indebted to Assoc. Prof. Luca Tacconi for providing partial financial support to conduct this research.

\section{REFERENCES}

Aguirre, O., Hui, G., Gadow, K. V., \& Jiménez, J. (2003). An analysis of spatial forest structure using neighbourhood-based variables. Forest Ecology and Management, 183(1-3), 137-145.

Akaike, H. (1974). A new look at the statistical model identification. IEEE Transactions on Automatic Control, 19(6), 716-723.

Akindele, S. O., \& LeMay, V. M. (2006). Development of tree volume equations for common timber species in the tropical rain forest area of Nigeria. Forest Ecology and Management, 226(1-3), 41-48.

Basuki, T. M., van Laake, P. E., Skidmore, A. K., \& Hussin, Y. A. (2009). Allometric equations for estimating the above-ground biomass in tropical lowland Dipterocarp forests. Forest Ecology and Management, 257(8), 1684-1694.

Brown, S. (1997). Estimating biomass and biomass change of tropical forests: a primer. Rome, Italy: Food and Agriculture Organization of the United Nations (FAO).

Brown, S. (2002). Measuring carbon in forests: current status and future challenges. Environmental Pollution, 116(3), 363-372.

Brown, S., Lugo, A. J. R., \& Gillespie, A. E. (1989). Biomass estimation methods for tropical forests with applications to forest inventory data. Forest Science, 35, 881-902.

Budhathoki, C. B., Lynch, T. B., \& Guldin, J. M. (2008). A Mixed-Effects Model for the dbh Height Relationship of Shortleaf Pine (Pinus echinata Mill.). Southern Journal of Applied Forestry, 32(1), 5-11.
Bullock, S. H. (2000). Developmental Patterns of Tree Dimensions in a Neotropical Deciduous Forest. Biotropica, 32(1), 42-52.

Calama, R., \& Montero, G. (2004). Interregional nonlinear height diameter model with random coefficients for stone pine in Spain. Canadian Journal of Forest Research, 34(1), 150163.

Castedo Dorado, F., Diéguez-Aranda, U., Barrio Anta, M., Sánchez Rodrígue, M., \& von Gadow, K. (2006). A generalized height-diameter model including random components for radiata pine plantations in northwestern Spain. Forest Ecology and Management, 229(1-3), 202-213.

Chave, J., Andalo, C., Brown, S. M., Cairns, J., Chambers, D., Eamus, H., ... Yamakura, T. (2005). Tree allometry and improved estimation of carbon stocks and balance in tropical forests. Oecologia, 145(1), 87-99.

Cobb, D. F., O'hara, K. L., \& Oliver, C. D. (1993). Effects of variations in stand structure on development of mixed-species stands in eastern Washington. Canadian Journal of Forest Research, 23(1), 545-552.

Cole, T. G., \& Ewel, J. J. (2006). Allometric equations for four valuable tropical tree species. Forest Ecology and Management, 229(1-3), 351-360.

Crow, T. R. (1978). Common Rregressions to estimate tree biomass in tropical stands. Forest Science, 24, 110-114.

Curtis, R. O. (1967). Height-Diameter and HeightDiameter-Age Equations For SecondGrowth Douglas-Fir, ,. Forest Science, 13, 365-375.

Ditzer, T., Glauner, R., Förster, M., Köhler, P., \& Huth, A. (2000). The process-based stand growth model Formix 3-Q applied in a GIS environment for growth and yield analysis in a tropical rain forest. Tree Physiology, 20(5-6), 367-381.

Djomo, A. N., Ibrahima, A., Saborowski, J., \& Gravenhorst, G. (2010). Allometric equations for biomass estimations in Cameroon and pan moist tropical equations including biomass data from Africa, ,. Forest Ecology and Management, 260(10), 1873-1885.

Fang, Z., \& Bailey, R. L. (1998). Height-diameter models for tropical forests on Hainan 
Island in southern China. Forest Ecology and Management, 110(1-3), 315-327.

Fehrmann, L., \& Kleinn, C. (2006). General considerations about the use of allometric equations for biomass estimation on the example of Norway spruce in central Europe,. Forest Ecology and Management, 236(23), 412-421.

Feldpausch, T. R., Banin, L., Phillips, O. L., Baker, T. R., Lewis, S. L., Quesada, C. A., ... Lloyd, J. (2011). Height-diameter allometry of tropical forest trees. Biogeosciences, 8(5), 1081-1106.

Gower, S. T., Kucharik, C. J., \& Norman, J. M. (1999). Direct and indirect estimation of leaf area index, fAPAR, and net primary production of terrestrial ecosystems. Remote Sensing of Environment, 70, 29-51.

Hara, T., Kimura, M., \& Kikuzawa, K. (1991). Growth Patterns of Tree Height and Stem Diameter in Populations of Abies veitchii, A. mariesii and Betula ermanii. Journal of Ecology, 79(4), 1085-1098.

Huang, S., Price, D., \& Titus, S. J. (2000). Development of ecoregion-based heightdiameter models for white spruce in boreal forests. Forest Ecology and Management,, 129(13), 125-141.

Huang, S., \& Titus, S. J. (1993). An index of site productivity for uneven-aged or mixedspecies stands, ,. Canadian Journal of Forest Research, 23(3), 558-562.

Huang, S., Titus, S. J., \& Wiens, D. P. (1992). Comparison of nonlinear height-diameter functions for major Alberta tree species. Canadian Journal of Forest Research, 22(9), 1297-1304.

Istomo. (2002). Kandungan fosfor dan kalsium serta penyebarannya pada tanah dan tumbuban butan rawa gambut: studi kasus di Wilayah Bagian Kesatuan Pemangkuan Hutan Bagan, Kabupaten Rokan Hilir, Rian (Ph.D thesis). Institut Pertanian Bogor, Bogor.

Jiang, L., \& Li, Y. (2010). Application of non-linear mixed effects modelling approach in tree height prediction. Journal of Computers, 5(10), 1575-1581.

Ketterings, Q. M., Coe, R., Noordwijk, M. van, Ambagau', Y., \& Palm, C. A. (2001). 2001. Reducing uncertainty in the use of allometric biomass equations for predicting aboveground tree biomass in mixed secondary forests. Forest Ecology and Management, 146(13), 199-209.

Krisnawati, H., Wang, Y., \& Ades, P. K. (2010). Generalized height-diameter models for Acacia mangium Willd. plantation in South Sumatra. Journal of Forestry Research, 7(1), 1-19.

Larsen, D. R., \& Hann, D. W. (1987). Height-diameter equations for seventeen tree species in soutbwest Oregon (Research Paper 49). Oregon: Forest Research Lab. Oregon State University.

Lee, Y. J., Coble, D. W., Pyo, J. K., Kim, S. H., Lee, W. K., \& Choi, J. K. (2009). A Mixed-effects Height-Diameter Model for Pinus densiflora Trees in Gangwon Province, Korea. Journal of Korean Forestry Society, 98(2), 178-182.

Lei, Y. C., \& Zhang, S. Y. (2004). Features and partial derivatives of Bertalanffy-Richards growth model in forestry. Nonlinear Analysis: Modelling and Control, 9(1), 65-73.

Litton, C. M., \& Kauffman, J. B. (2008). Allometric models for predicting above-ground biomass in two widespread woody plants in Hawaii. Biotropica, 40(3), 313-320.

Nelson, B. W., Mesquita, R., Pereira, J. L. G., Souza, S., de Souza, S. G. A., Batista, G. T., \& Couto, L. B. (1999). Allometric regressions for improved estimate of secondary forest biomass in the central Amazon. Forest Ecology and Management, 117(1-3), 149-167.

Nogueira, E. M., Nelson, B. W., Fearnside, P. M., França, M. B., \& Oliveira, Á. C. A. d. (2008). Tree height in Brazil's "arc of deforestation": Shorter trees in south and southwest Amazonia imply lower biomass. Forest Ecology and Management, 255(7), 2963-2972.

Okuda, T., Suzuki, M., Numata, S., Yoshida, K., Nishimura, S., Adachi, N., ... Hashim, M. (2004). Estimation of above-ground biomass in logged and primary lowland rainforests using 3-D photogrammetric analysis. Forest Ecology and Management, 203(1-3), 63-75.

Overman, J. P. M., Witte, H. J. L., \& Saldarriaga, J. G. (1994). Evaluation of regression models for above-ground biomass determination in Amazon rainforest. Journal of Tropical Ecology, 10(02): 207-218. 
Parresol, B. R. (1992). Baldcypress height-diameter equations and their prediction confidence intervals. Canadian Journal of Forest Research, 22(9), 1429-1434.

Parresol, B. R. (1999). Assessing tree and stand biomass: a review with examples and critical comparisons. Forest Science, 45, 573-593.

Paulo, J., Tomé, J., \& Tomé, M. (2011). Nonlinear fixed and random generalized heightdiameter models for Portuguese cork oak stands. Annals of Forest Science, 68(2), 295309.

Peng, C., Zhang, L., \& Liu, J. (2001). Developing and Validating Nonlinear Height-Diameter Models for Major Tree Species of Ontarios Boreal Forests. Northern Journal of Applied Forestry, 18(3), 87-94.

Peng, C., Zhang, L., Zhou, X., Dang, Q., \& Huang, S. (2004). Developing and Evaluating Tree Height-Diameter Models at Three Geographic Scales for Black Spruce in Ontario, Northern. Journal of Applied Forestry, 21(2), 83-92.

Pilli, R., Anfodillo, T., \& Carrer, M. (2006). Towards a functional and simplified allometry for estimating forest biomass. Forest Ecology and Management, 237(1-3), 583-593.

Ratkowsky, D. A. (1990). Handbook of Nonlinear Regression Models. New York, USA: Marcel Dekker.

Ratkowsky, D. A., \& Reedy, T. J. (1986). Choosing Near-Linear Parameters in the FourParameter Logistic Model for Radioligand and Related Assays. Biometrics, 42(3), 575582.

Richards, F. J. (1959). A Flexible Growth Function for Empirical Use. Journal of Experimental Botany, 10(2), 290-301.

Saldarriaga, J. G., West, D. C., Tharp, M. L., \& Uhl, C. (1988). Long-Term Chronosequence of Forest Succession in the Upper Rio Negro of Colombia and Venezuela. Journal of Ecology, 76(4), 938-958.

Sánchez, C. A. L., Varela, J. G., Dorado, F. C., Alboreca, A. R., Soalleiro, R. R., González, J. G. Á., \& Rodríguez, F. S. (2003). A heightdiameter model for Pinus radiata D. Don in Galicia (Northwest Spain). Annals of Forest Science, 60(3), 237-245.
SAS Institute Inc. (2009). JMP® 8 User Guide. Cary, NC: SAS Institute Inc.

Schnute, J. (1981). A versatile growth model with statistically stable parameters. Canadian Journal of Fisheries and Aquatic Sciences, 38(9), 1128-1240.

Segura, M., \& Kanninen, M. (2005). Allometric Models for Tree Volume and Total Aboveground Biomass in a Tropical Humid Forest in Costa Rica. Biotropica, 37(1), 2-8.

Sharma, M., \& Parton, J. (2007). Height-diameter equations for boreal tree species in Ontario using a mixed-effects modeling approach. Forest Ecology and Management, 249(3), 87-198.

Sharma, M., \& Zhang, S. Y. (2004). Height-Diameter Models Using Stand Characteristics for Pinus banksiana and Picea mariana. Scandinavian Journal of Forest Research, 19(5), 442-451.

Snowdon, P. (1991). A ratio estimator for bias correction in logarithmic regressions. Canadian Journal of Forest Research, 21, 720724.

Soares, P., \& Tomé, M. (2002). Height-diameter equation for first rotation eucalypt plantations in Portugal. Forest Ecology and Management, 166(1-3), 99-109.

Stout, B. B., \& Shumway, D. L. (1982). Site Quality Estimation Using Height and Diameter. Forest Science, 28(3), 639-645.

Temesgen, H., \& Gadow, K. v. (2004). Generalized height-diameter models-an application for major tree species in complex stands of interior British Columbia. European Journal of Forest Research, 123(1), 45-51.

Temesgen, H., Hann, D. W., \& Monleon, V. J. (2007). Regional height-diameter equations for major tree species of southwest Oregon. Western Journal of Applied Forestry, 22, 213219.

Temesgen, H., Monleon, V. J., \& Hann, D. W. (2008). Analysis and comparison of nonlinear tree height prediction strategies for Douglas-fir forests. Canadian Journal of Forest Research, 38(3), 553-565.

Thomas, S. C. (1996). Asymptotic height as a predictor of growth and allometric characteristics in Malaysian rain forest trees. American Journal of Botany, 83(5), 556-566. 
Uhl, C., Buschbacher, R., \& Serrao, E. A. S. (1988). Abandoned Pastures in Eastern Amazonia. I. Patterns of Plant Succession. Journal of Ecology, 76(3), 663-681.

Vanclay, J. K. (1992). Assessing site productivity in tropical moist forests: a review. Forest Ecology and Management, 54, 257-287.

Vanclay, J. K. (1994). Modelling Forest Growth and Yield. Wallingford, UK: CAB International.

VanderSchaaf, C. L. (2008). Stand level heightdiameter mixed effects models: parameters fitted using loblolly pine but calibrated for sweetgum. In D. F. Jacobs \& C. H. Michler (Eds.), Proceedings $16^{\text {th }}$ Central Hardwoods Forest Conference, Vol. Gen. Tech. Rep. NRS-P-24. Newtown Square, PA: U.S. Department of Agriculture, Forest Service, Northern Research Station.

Verwer, C. C., \& Meer, P. J. v. d. (2010). Carbon pools in tropical peat forest - Toward a reference value for forest biomass carbon in relatively undisturbed peat swamp forests in Southeast Asia. Wageningen, The Netherlands: Alterra-report 2108.

Wahyunto, Ritung, S., Suparto, \& Subagjo, H. (2005). Sebaran Gambut dan Kandungan Karbon di Sumatera dan Kalimantan, Climate Change, Forests and Peatlands in Indonesia Project. Wetlands International-Indonesia Programme and Wildlife Habitat. Bogor: Wetlands InternationalIndonesia Programme and Wildlife Habitat Canada.

Wang, C. (2006). Biomass allometric equations for 10 co-occuring tree species in Chinese temperate forests. Forest Ecology and Management, 222, 9-16.

Wang, C. H., \& Hann, D. W. (1988). Height-diameter equations for sixteen tree species in the central Willamette Valley of Oregon (Research Paper 51). Oregon: Forest Research Lab., Oregon State University.

Yamakura, T., Hagihara, A., S. Sukardjo, \& Ogawa, H. (1986). . Above-Ground biomass of tropical rain forest stands in Indonesian Borneo. Plant Ecology, 68(2), 71-82.

Yang, R. C., Kozak, A., \& Smith, J. H. G. (1978). The potential of Weibull-type functions as a flexible growth curves. Canadian Journal of Forest Research, 8, 424-431.
Yuancai, L., \& Parresol, B. R. (2001). Remarks on height-diameter modeling (Research Note SRS-IO). Asheville, NC: United States Department of Agriculture, Forest Service, Southern Research Station.

Zeide, B. (1993). Analysis of Growth Equations. Forest Science, 39(3), 594-616.

Zhang, L. (1997). Cross-validation of non-linear growth functions for modelling tree heightdiameter relationships. Annals of Botany, 79, 251-257.

Zhang, L., Bi, H., Cheng, P., \& Davis, C. J. (2004). Modeling spatial variation in tree diameterheight relationships, Forest Ecology and Management,. Forest Ecology and Management, 189(1-3), 317-329.

Zhou, X., Peng, C., Dang, Q.-L., Chen, J., \& Parton, S. (2005). Predicting forest growth and yield in northeastern Ontario using the processbased model of TRIPLEX1.0. Canadian Journal of Forest Research, 35(9), 2268-2280. 
APPENDIX 1. Tree species used to develop site specific $H-D$ models and their statistical summaries

\begin{tabular}{|c|c|c|c|c|c|c|c|c|c|c|c|}
\hline \multirow[t]{2}{*}{ No. } & \multicolumn{2}{|r|}{ Species Name } & \multicolumn{9}{|c|}{ Statistical summary } \\
\hline & Local & Scientific & $\begin{array}{c}D_{\min } \\
(\mathrm{cm})\end{array}$ & $\underset{(\mathrm{max})}{D_{\max }}$ & $\begin{array}{c}D_{\text {mean }} \\
(\mathrm{cm})\end{array}$ & $\begin{array}{c}D_{S D} \\
(\mathrm{~cm})\end{array}$ & $\underset{(m)}{H_{m i n}}$ & $\underset{\text { (m) }}{H_{\max }}$ & $\underset{\text { mean }}{H_{(m)}}$ & $\begin{array}{c}H_{S D} \\
(\mathrm{~m})\end{array}$ & $n$ \\
\hline 1 & Arang-arang & Myristica lowiana King. & 7.3 & 67.3 & 48.9 & 24.1 & 7.8 & 39.3 & 30.2 & 12.6 & 8 \\
\hline 2 & Asam-asam & Santiria griffithii (Hook.f.) Engl. & 8.5 & 14.0 & 11.3 & 3.9 & 10.5 & 12.3 & 11.4 & 1.2 & 2 \\
\hline 3 & Balam & Palaquium obovatum (Griffith) Enql. & 7.6 & 61.3 & 36.0 & 16.1 & 7.8 & 36.3 & 25.2 & 8.3 & 15 \\
\hline 4 & Bintangur & Calopbyllum soulattri Burm.f. & 7.8 & 7.8 & 7.8 & NA & 10.5 & 10.5 & 10.5 & NA & 1 \\
\hline 5 & Darah-darah & Horsfieldia glabra (Blume) Warb. & 5.4 & 33.0 & 17.7 & 12.0 & 7.4 & 26.6 & 16.0 & 8.0 & 7 \\
\hline 6 & Durian burung & Durio carinatus Masters & 6.4 & 63.5 & 43.3 & 32.0 & 8.9 & 39.0 & 27.9 & 16.5 & 3 \\
\hline 7 & Geronggang & Cratoxylum arborescens (Vahl.) Blume. & 6.3 & 112.0 & 66.1 & 26.2 & 6.9 & 39.1 & 32.0 & 8.5 & 19 \\
\hline 8 & Jambu-jambu & Eugenia sp. L. & 7.8 & 33.1 & 18.7 & 8.5 & 9.3 & 19.8 & 15.3 & 3.8 & 8 \\
\hline 9 & Jangkang & Xylopia malayana Hook.f. et. Th. & 10.1 & 10.7 & 10.4 & 0.4 & 13.4 & 14.2 & 13.8 & 0.5 & 2 \\
\hline 10 & Kapas-kapas & Unknown & 35.3 & 47.2 & 41.3 & 8.4 & 25.4 & 35.1 & 30.2 & 6.8 & 2 \\
\hline 11 & Katiau & Ganua motleyana (de Vriese) Piere ex D. & 24.2 & 37.5 & 30.9 & 9.4 & 23.7 & 28.5 & 26.1 & 3.3 & 2 \\
\hline 12 & Kelat & Carallia brachiata (Lour.) Merr. & 8.3 & 25.1 & 14.0 & 6.9 & 7.9 & 23.8 & 14.5 & 6.3 & 5 \\
\hline 13 & Kenari & Santiria laevigata Blume. & 6.7 & 14.7 & 10.5 & 4.0 & 9.0 & 14.2 & 10.8 & 2.9 & 3 \\
\hline 14 & Keranji & Dialium modestum (v.Steen) Stey & 5.7 & 5.7 & 5.7 & NA & 7.4 & 7.4 & 7.4 & NA & 1 \\
\hline 15 & Kopi-kopi & Gardenia sp. & 7.6 & 7.6 & 7.6 & NA & 6.7 & 6.7 & 6.7 & NA & 1 \\
\hline 16 & Mahang & Macaranga semiglobosa J.J.S. & 6.6 & 12.4 & 9.5 & 4.1 & 8.5 & 17.3 & 12.9 & 6.2 & 2 \\
\hline 17 & Manggis-manggis & Garcinia celebica (Burm.) L. & 6.0 & 31.2 & 20.2 & 10.8 & 6.9 & 21.4 & 16.0 & 6.3 & 4 \\
\hline 18 & Medang telor & Lindera subumbliiflora Kosterm. & 7.3 & 19.2 & 12.2 & 6.2 & 12.9 & 17.4 & 15.3 & 2.2 & 3 \\
\hline 19 & Mengkal udang & Timonius sp. & 7.0 & 7.0 & 7.0 & NA & 7.0 & 7.0 & 7.0 & NA & 1 \\
\hline 20 & Meranti anak & Spondias pinnata (J. Konig ex L. f.) Kurz & 8.4 & 103.0 & 63.9 & 30.0 & 8.9 & 51.7 & 34.8 & 12.5 & 12 \\
\hline 21 & Meranti batu & Shorea uliginosa Foxw. & 6.4 & 92.0 & 56.2 & 18.0 & 6.4 & 50.1 & 35.6 & 7.5 & 64 \\
\hline 22 & Meranti bunga & Shorea teysmanniana Dyer ex Brandis & 9.0 & 96.3 & 54.2 & 24.3 & 9.8 & 51.2 & 33.1 & 11.2 & 12 \\
\hline 23 & Milas & Parastemon urophyllum (Wallich. ex A. DC) A.DC & 7.6 & 54.5 & 27.6 & 16.9 & 11.5 & 33.4 & 24.9 & 7.9 & 7 \\
\hline 24 & Nangka-nangka & Neoscortechinia kingii Hook. F. & 6.4 & 11.0 & 8.7 & 3.3 & 8.0 & 11.6 & 9.8 & 2.5 & 2 \\
\hline 25 & Nyatoh & Palaquium rostratum (Miq.) Burck. & 38.5 & 38.5 & 38.5 & NA & 24.9 & 24.9 & 24.9 & $\mathrm{NA}$ & 1 \\
\hline 26 & Pasak linggo & Aglaia rubiginosa (Hiern.) Pannell. & 8.0 & 43.0 & 27.4 & 16.1 & 13.6 & 33.0 & 24.7 & 9.4 & 5 \\
\hline 27 & Pasir-pasir & Ilex macrophylla Hook. F. & 6.4 & 54.4 & 23.4 & 17.8 & 7.6 & 27.9 & 16.6 & 7.9 & 10 \\
\hline 28 & Pisang-pisang & Mezzettia parvifora Becc. & 7.3 & 54.3 & 37.0 & 17.0 & 9.1 & 41.4 & 27.8 & 9.7 & 9 \\
\hline 29 & Pulai & Alstonia pneumatophora Backer ex den Berger & 10.4 & 116.4 & 77.5 & 21.2 & 10.5 & 51.7 & 39.5 & 7.6 & 29 \\
\hline 30 & Punak & Tetramerista glabra Miq. & 9.2 & 74.2 & 51.2 & 25.2 & 7.0 & 28.0 & 21.3 & 8.2 & 5 \\
\hline 31 & Ramin & Gonystylus bancanus (Miq.) Kurz. & 5.2 & 89.0 & 48.9 & 24.7 & 8.1 & 40.0 & 31.3 & 10.1 & 13 \\
\hline 32 & Selumar & Jackiopsis ornata (Wallich) Ridsd. & 8.4 & 11.2 & 9.8 & 2.0 & 11.6 & 13.1 & 12.4 & 1.0 & 2 \\
\hline 33 & Serapat & Calophyllum macrocarpum Hook. F. & 47.0 & 73.4 & 62.9 & 12.5 & 32.5 & 40.5 & 35.7 & 3.5 & 4 \\
\hline 34 & Simpur & Dillenia excelsa (Jack) Gilg. & 6.0 & 35.4 & 17.0 & 16.0 & 8.1 & 27.6 & 15.7 & 10.3 & 3 \\
\hline 35 & Suntai & $\begin{array}{l}\text { Palaquium dasyphyllum (de Vriese) Pierre ex } \\
\text { Dubard }\end{array}$ & 7.3 & 7.3 & 7.3 & NA & 8.4 & 8.4 & 8.4 & NA & 1 \\
\hline 36 & Terentang & $\begin{array}{l}\text { Campnosperma coriaceum (Jack.) Hallier f. ex v. } \\
\text { Steenis }\end{array}$ & 9.6 & 52.5 & 33.8 & 14.8 & 10.2 & 34.2 & 23.4 & 8.9 & 10 \\
\hline 37 & Terpis & Polyaltbia glauca (Hassk.) F. v. Mueller & 5.7 & 27.8 & 15.7 & 11.1 & 5.3 & 30.7 & 18.0 & 12.6 & 4 \\
\hline \multirow[t]{2}{*}{38} & Timah-timah & Ilex pleiobrachiata Loes. & 6.0 & 13.5 & 9.5 & 3.4 & 7.8 & 13.3 & 10.6 & 2.8 & 4 \\
\hline & & All species & 5.2 & 116.4 & 45.2 & 27.5 & 5.3 & 51.7 & 28.2 & 12.0 & 286 \\
\hline
\end{tabular}

Notes : $D=$ diameter at breast height, $H=$ total tree height, $n=$ number of sample, $\min =$ minimum, $\max =$ maximum, mean $=$ average, $S D=$ standard deviation, and $N A=$ not applicable 
APPENDIX 2. Scatter plots of regression studentized residuals against predicted height for each developed model: (a) Model 1, (b) Model 2, (c) Model 3, (d) Model 4, (e) Model 5, (f) Model 6, and (g) Model 7

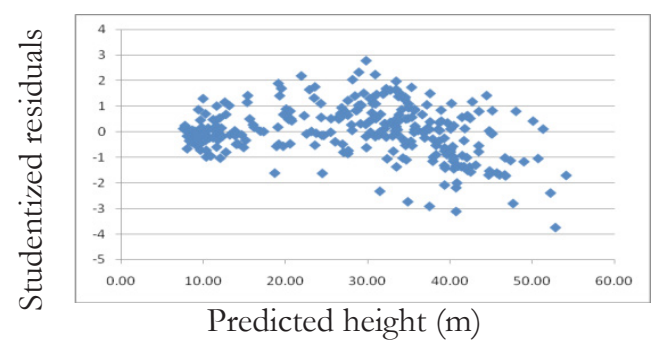

(a)

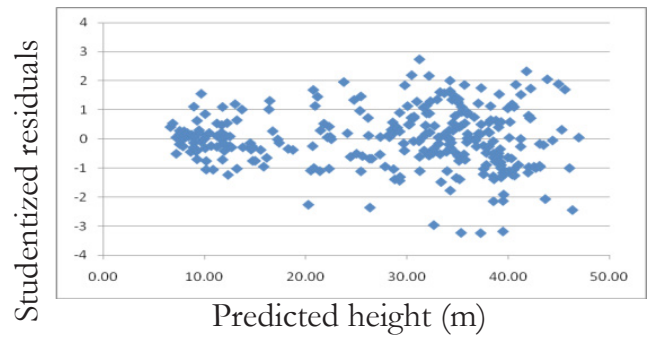

(b)

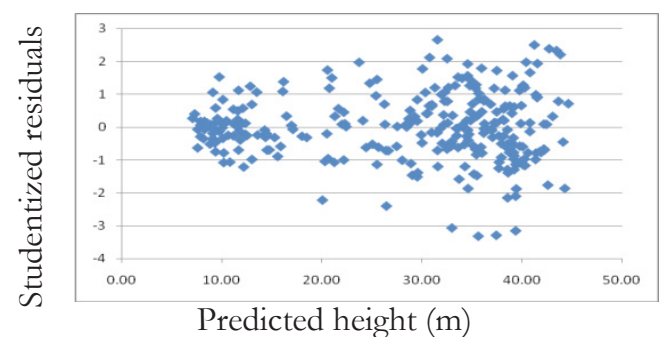

(c)
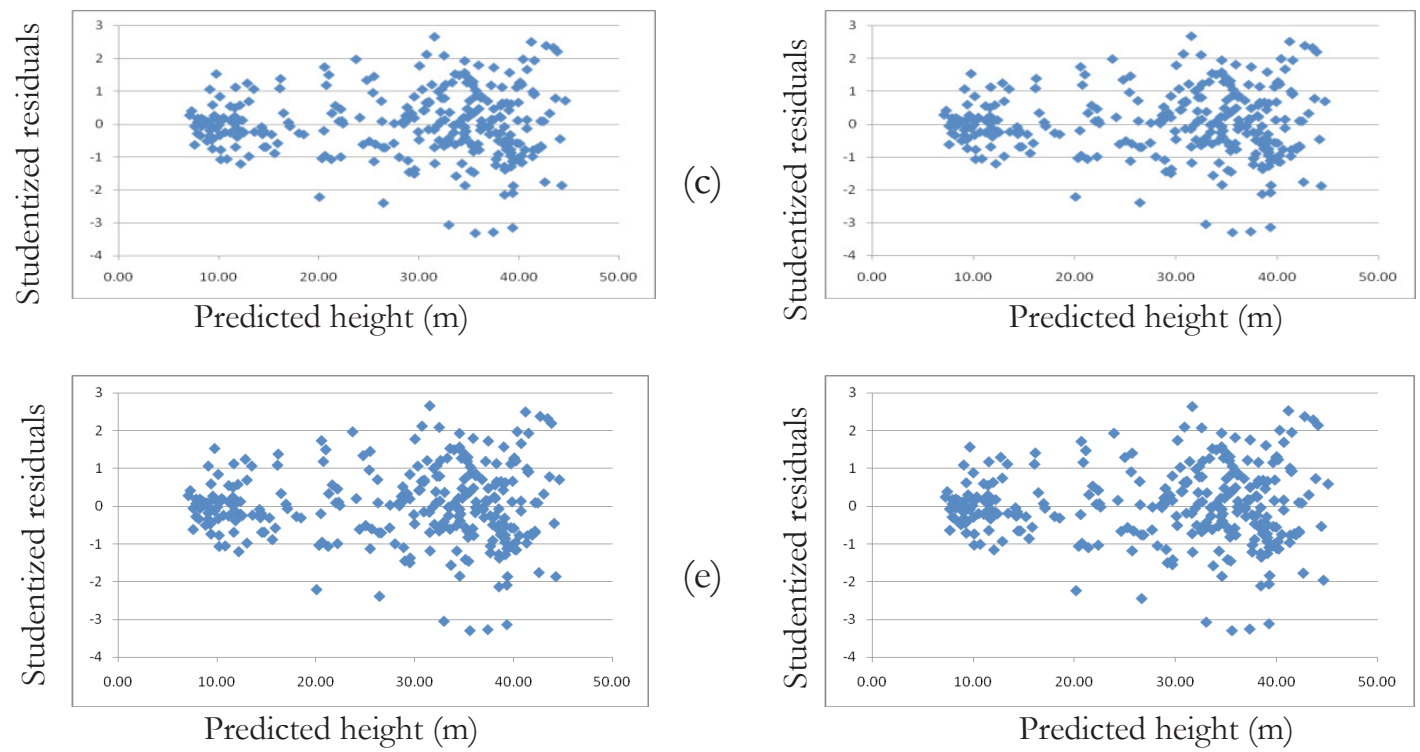

(e)

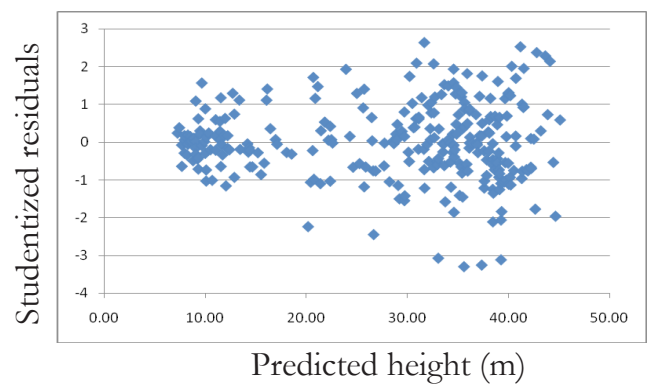

(d)

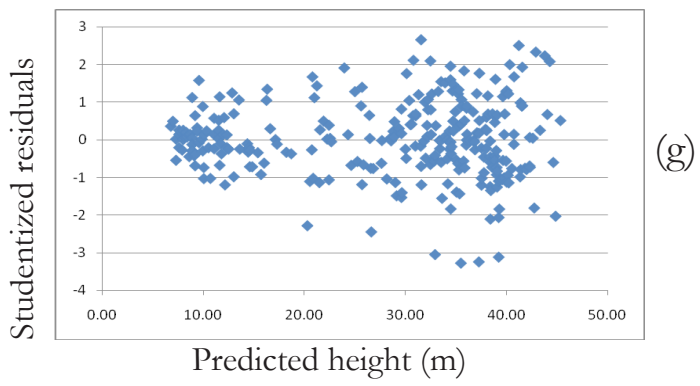

